\title{
Unleashing the Indirect Influence of FDI in Environmental Degradation via Financial Development and Economic Growth. New Evidence from Asian Countries
}

Ghulam Muhmmad Qamri ( $\square$ m.anwar.ims@gmail.com )

Beijing University of Technology

\section{Bing Sheng}

Nankai University

\section{Rana Ejaz Ali Khan}

The Islamia University of Bahawalpur Pakistan

\section{Wasisfah Hanim}

Universitas Widyatama

\section{Research}

Keywords: Foreign direct investment, financial development, economic growth, environmental degradation, Asian countries

Posted Date: June 18th, 2020

DOI: https://doi.org/10.21203/rs.3.rs-32631/v1

License: (a) (1) This work is licensed under a Creative Commons Attribution 4.0 International License. Read Full License 


\section{Abstract}

\section{Background:}

Scholars in developed and emerging economies have widely tested the interactions between foreign direct investment, financial development, economic growth and environmental degradation. Despite a number of empirical and review studies, it is not yet wrap up either the associations are negative, positive, direct or indirect. Additionally, minor attention is given to the indirect role of foreign direct investment in environmental degradation; perhaps no study has yet demonstrated the mediating role of financial development and economic growth between foreign direct investment and environmental degradation in Asian economies. Referring to the fragmented outputs and consequences as well as lacking the indirect role, the present study examines the influence of foreign direct investment on environmental degradation with the mediating role of financial development and economic growth.

\section{Results:}

Secondary data of 21 Asian countries from 1980-2018 were gathered from World Bank Indicators and then performed STATA to test the paths. Our findings are slightly different from the studies conducted in developed economies. The results indicate that foreign direct investment significantly improves environmental quality by deteriorating environmental pollution. It also significantly improves economic growth in the selected regions. Surprisingly, our study shows that foreign direct investment has a significant negative influence on financial development in the Asian regions. Both financial development and economic growth significantly negatively influence environmental degradation in Asian regions. However, financial development partially mediates while economic growth does not play any mediating role between foreign direct investment and environmental degradation in the Asian countries. Trade openness and population growth as control factors do not show any significant role in the model.

\section{Conclusions:}

This research recommends policymakers to focus on the inflow of foreign direct investment in order to enhance economic growth and environmental quality. It is strongly suggested for policymakers to attenuate the political intervention (e.g. ensure the political stability) in the inflow of foreign direct investment, so financial resources can be impartially distributed in the industrial sector and thus the nations will have an effective financial development system. Other implications have described.

\section{Introduction}

Environmental Degradation (ED) is the depletion of natural resources such as soil, water and air that damages the ecosystem, habitats destruction; eliminates wildlife; and pollution. Over the past 50 years, ED has become a global issue and every country (e.g. developed and developing) faces the dangers. For instance, as pointed out by Gorus and Aslan [1] after the second half of the $20^{\text {th }}$ century, climate change and global warming have been the sternest environmental complications. The greenhouse effect is the topmost suspicious in these two interrelated glitches. $\mathrm{CO}_{2}$ has been significantly increased and has challenged 
individuals as well as nations [2-4]. The negative environmental consequences have not only distrusted Economic Growth (EG) but have also damaged living standards across the globe $[5,6]$.

For the last several decades, there has been a devastating number of studies evaluating the factors affecting environment degradation. In other words, the influence of a variety of factors such as Foreign Direct Investment (FDI) [7-9], Financial Development (FD) [10, 11], EG [12, 13], energy consumption [14, 15], global warming ([16]), climate change $[17,18]$ and ITC [19] etc. Considering the adverse effect of ED, countries across the globe are in search of effective strategies, policies, and programs to respond to it [18, 20,21]. Many developed economies have initiated effective programs to avoid the negative outcomes of ED but emerging economies have still lack policies for such issues $[22,23]$. Perhaps the main issue of this in low income and emerging economies is lack of resources and lack of support [24]. Hence, countries with low income and especially emerging economies have been focused inflow of FDI as a main source to attenuate the adverse influence of ED [1]. This notion has been supported by a plethora of literature [25-27]. However, it is still elusive either FDI directly contributes to ED or it first promote FD and EG which in turn facilitate ED. To clear the ambiguity, this study aims to unleash the direct or indirect role of FDI in ED via FD and EG.

The novelty of this study is categorized in two ways. First, despite bourgeoning literature, the question is still tantalizing either FDI has a positive or negative influence on ED? For instance, some studies such as [28-30] have revealed a positive influence while other studies [31,32] [33], and [34] have claimed a negative influence. Considering the fragmented results derived from the existing literature, this study collects evidence from Asian countries to test either the relationship between FDI and ED is negative or positive. Second, most of the studies have tested the direct influence of FDI while factors such as FD and EG as mediators have been missed. Though, studies have claimed that FDI significantly influences FD [35, 36] and EG [37-39]. Therefore, it is very important to test if certain factors; FD and EG can mediate the relationship. Testing this zone can perhaps clear the idea why some studies scrutinized a direct negative path between FDI and ED. This study tests the model on the empirical evidence gathered from Asian economies. The reasons for choosing Asian economies are that most of the countries in Asia are placed in low-income countries who are unable to respond to ED unless they receive adequate support in the form of FDI [40]. Asian countries have not yet initiated effective programs and policies to attenuate the adverse influence of ED [41]. As mentioned earlier, this study benefits especially Asian markets to protect their environment, enhance FD and spur their EG by encouraging and promoting the inflow of FDI. Additionally, Asian counties face a big pressure of ED due to unexpected climate change, natural catastrophe and deficient resources etc. For this research, we considered the Asian countries named; Bangladesh, Brunei, China, Bhutan, Fuji, Maldives, India, Indonesia, Kiribati, Leo, Malaysia, Magnolia, Myanmar, Pupa New, Nepal, Philippine, Solomon, Samoa, Sri Lanka, Thailand and Tonga.

The findings can help policymakers and responsible authorities in Asian economies to build and initiate strategic policies for environmental issues and threats. They can promote FDI and investment to protect the environment and facilitate the greenness. Countries with low economies can get attention for investment to be done by advanced and high-income economies. Seeing the alternative benefits, recently emerging economies in Asia have attracted FDI due to its significant role in EG, Job opportunities, technologies, 
management skills and market growth [6]. Therefore, the findings will benefit policymakers to encourage the inflow of FDI toward emerging economies.

This research contributes to The Kuznets curve hypothesis and Pollution haven hypothesis [42]. The Kuznets curve hypothesis claims that as an economy grows, market forces increase and then gradually declines due to economic inequality. It alternatively demonstrates that when foreign investors perceive a high growth in an economy, they tend to invest in the industrial sector that also benefits environmental activities in the host nation. Pollution heaven hypothesis demonstrates that when large firms/organizations/a nation aims to set up their operational and environmental activities in other markets, they need cheap resources and support [42]. In our study, we perceive that FDI can provide such advantages to the host firms to settle their business activities and to participate in environmental activities.

\section{Theoretical Background}

Considering the conceptual model of the study, it is worthy to scope all the relevant theories that can partially or fully support the paths. Therefore, the most relevant theories aligned with our model are EKCT and pollution heaven hypothesis. Both theories are stated in a proper way to display the links among the factors. Simon Kuznets [43] was the first one who proposed the Kuznets curve hypotheses, displays that as an economy develops, preliminary variation increases and later slowly shrinkages [43]. Researchers link this phenomenon to the positive signals for investors who see intend to invest in a country that is growing and have more investment opportunities $[6,44,45]$. This, in turn, advantages environmental quality and protection. The Kuznets curve line displays that when a nation experience industrialization and agriculture mechanization, the economic epicenter of the state will exchange to urban areas [6, 46]. Hence, farmers incline to gather into big cities for the purpose of getting highly paid jobs. It means there is a big gap and inequality between rural and urban areas. Since the urban population becomes rich while the rural population shifts toward poverty because firms' owners enjoy higher profit over labors in a particular industry. Nevertheless, the gap (inequality) then drops when EG touches the peak theme of mediocre revenue and the wellbeing of the nation reach from development to democratization, assists high growth and leading to an upward GDP per capita. Kuznets describes that inequality would have a tendency like an overturned Ushape as it first improves and then declines along with the increased of GPD. In fact, the Kuznets curve demonstrates an inverted U-shape curve, many predictors with axes that are normally matched and jointed, such as the Gini coefficient on the Y-axis and GDP and time and ED on the X-axis. With the passage of time and around a few decades later, Grossman and Krueger, [47] tested this premise in the environmental context. It displays that ED and economic development have an upturned U-shaped association which is referred to as the Environmental Kuznets curve theory (EKCT). For instance, the EKCT describes that ED and fiscal progress have a positive association. When a nation growing in the first phase, the living standard of people may be the expenditure of the atmosphere. But on the achievement of high economic growth, uncertainties about the ecosystem and environment begin (Figure 1). The reversed U-shaped results of the EKC curve is supported by many empirical pieces of evidence such as Shafik [48] and [49]. It has become very popular in shaping ecological strategy. Onafowora and Owoye's [50] claimed that the long-run connection between ED and economic development presents an N-shape. However, Al-Mulali and Ozturk [51] shown a U-shaped association between ED and GDP. 
How EKC works in an economy over time is described in Figure 1. It demonstrates that a country becomes an economic ladder, the influence of the growth can cause an upturn in ED. It is the portion of the Kuznets curve before $\mathrm{E}$ point (a rotating point), there is a rational and useful logic behind a growing economy displaying an upward ED. As income increasing (due to FDI) in an economy, its production level will increase. The benefits of high production facilitate the economy in the ED. In Figure 1, point $E$ is the turning point which shows that ED makes a U-turn and declines as EG upsurges. However, after point E, despite an upward shift in the income, ED moves to deterioration, and the EKC ends up as an inverted U-shape association. Apergis et al. [52] collected evidence from mixed regions and indicated an interconnection among energy practice, emissions, and income. Another data sample of high, middle and low-income countries displays an inverted U-shaped relationship between emissions and income economies and has supported the EKC theme [53]. Regarding EKC, the idea of the pollutionhavenhypothesis is worthy. According to the hypothesis, in a country where there are strict environmental regulations, it is expensive for big businesses to achieve environmentally worsening maneuvers. In contrast, in evolving economies where environmental rules are not so strict, it is not so difficult to operate a polluting industry and labor is also not expensive. Hence most of the factories try to move to developing economies where there are less expensive labors and lower environmental regulations [54].

The second theory that is affiliated with our model is "the pollution heaven hypothesis" is also discussed on this issue which describes that industries with high pollution will be shifted to the domains where less rigorous environmental regulations have existed. There are two major benefits of FDI for a host country. First, FDI can reduce ED through technological innovation. Second, it is argued that FDI specifically focuses on environmental issues which increase environmental pollution where polluting industries can be shifted from rich to poor nations due to lack of ecological procedures in the host nations.

Figure 1. Environmental Kuznets curve.

\section{Hypotheses Development}

\section{FDI and Environmental Degradation}

Environmental pollution has become a serious problem in developing and developed economies across the globe due to an increased level of change in industrial growth. A number of policies and strategies have been formulated to enhance the environmental quality [55-57]. Despite active engagement and programs, many countries, especially from Asia, have failed to gain satisfactory environmental performance [31, 58] due to a deficiency of resources and support $[25,59]$. In this case, out of several indicators, FDI has been considered a significant predictor of $\operatorname{ED}[3,8,57]$. However, there is a controversial documentary on the role of FDI in the ED. For instance, it is argued that the effects of the FDI can go any way, such as they may have positive effects in the form of the sustainability and FD of the economy, but at the same time they have negative effects on the environmental phenomena of the country. However, it depends on the sector, the FDI is targeting. Considering these backgrounds, there may be three different hypotheses related to these relationships between the FDIs and the environmental hazards, such as the first one is the pollution haven hypothesis, the next one is the pollution halo hypothesis, and finally the third one is the scale effects hypothesis [28]. Theoretically speaking, there could be a myriad of different belongings of the FDI on the 
environmental dimension of the nation. For example, these FDIs would affect the quality of the environment, however, the empirical evidence in this regard as divergent. For example, in China, an empirical study demonstrated that one of the major consequences of the FDIs is the high levels of emission of the $\mathrm{CO}_{2}[6]$. These results are contrary to the opinions of [28] who analyzed the BRICS and argued that the FDI is more effective in developing greener technologies, which benefits the host countries, which ultimately improves the overall environmental conditions of the host country. Supplementing to this discussion, [29] while considering the China at regional level units of analysis demonstrated the positive effects of the FDI on the environment such as improved and greener technologies, while on the same time, [31]and [32] while considering the City-Level data from China also reports that there are severe negative consequences of the FDI on the environmental deterioration, such as increased range of $\mathrm{CO}_{2}$ emissions in the areas received higher levels of the FDIs. Such contradictory results, even from a single country warrants more detailed studies considering the effects of the FDI on the environmental conditions of the countries. Furthermore, the evidence forms the other developing countries also report that although the FDI illustrates a favorable link with the EG of these countries, at the same time they have severe negative effects of the FDI on the EDs, particularly, in Malaysia [33] and Taiwan [34].

More surprisingly, in Taiwan, income and FDI are the two major contributors to the increased level of $\mathrm{CO}_{2}$ emissions [30]. While expanding the sample to other countries, particularly, the ASEAN countries, such as 5 countries, also suggests that the increased level of the FDIs results in a high range of energy expenditure, which ultimately leads to the increased level of $\mathrm{CO}_{2}$ emission [60]. However, another study conducted on the same ASEAN countries, suggested that there are FDIs and the $\mathrm{CO}_{2}$ are negatively related to each other [3]. In contrast, [61]conducted another study on these 5 countries while using the Pooled Mean Group (PMG) estimation technique in the dynamic panel and demonstrated that FDI inclines to produce more $\mathrm{CO} 2$. Paramati et al. [62] also demonstrated that FDIs inflow has a positive, significant effect on the clean energy consumption emission levels of the $\mathrm{CO} 2$. Considering these surprisingly contradictory pieces of evidence even within the same set of countries, it is important to see the main causes of these differences in exhibiting the contradictory relationships between the FDIs and the environmental hazards. It is very important for the economists while making policies to ponder the republic level heterogeneity in order to see the underlying mechanism which affects the direct association between the FDIs and the $\mathrm{CO}_{2}$ emissions.

Sbia et al. [63] demonstrated that the FDIs in the Middle Eastern countries would make them consume more green energy and would result in emission of more $\mathrm{CO}_{2}$ which would deteriorate the environment two-fold, one in decreasing the green energy and second, increase the $\mathrm{CO}_{2}$ emission particularly, in United Arab Emirates (UAE). GCC countries also show similar relationships, but in the long - run, as there are no shreds of evidence of a affirmative rapport between the FDIs and $\mathrm{CO}_{2}$ emission in the petite track [64]. Contrary to that, [65]demonstrated that there is a uni-directional causal relationship between the FDIs and the $\mathrm{CO}_{2}$ emissions in the MENA countries, however, they had country-level differences in exhibiting the positive relationship between the FDIs and the $\mathrm{CO}_{2}$. The results are also mixed in the 6 sub-saharan countries [66], while in the case of Ghana [67], the FDI has a constructive influence on the emission level of $\mathrm{CO}_{2}$. These differences are attributed to the idiosyncratic nature of the individual countries which differ from each other radically, which is one of the main reasons for the mixed results in terms of the liaison between the FDIs and 
the emission of the $\mathrm{CO}_{2}$. These mixed experimental consequences about FDI and the environmental hazards also imply the prominence and seeing country-level peculiarities, which could serve as the catalyst for the environmental deterioration, which is the rationale to focus on the developing countries, where there are different countries which are radically different from each other and may respond to the FDIs differently as expected.

It is also worthy to contemplate the development stage, inter alia, of the country while assessing the impact of the FDIs on the environmental hazards, such as [68]reported that FDI leads to a decreased level in the energy intensity; and argued that there may be new technological advancements in the country which could be the result of the FDIs in the country. However, in the case of the G-20 countries, there is no momentous connection between the $\mathrm{CO}_{2}$ and the FDIs [69]. Similarly, [56] while considering the three different categories of countries such as low, medium and high-income nations also exhibited that FDI poses environmental hazards for the countries which support the pollution-haven hypothesis $(\mathrm{PHH})$. To see the sectoral level differences in the OECD countries, [70] demonstrated that analysis on OECD countries, indicates that FDIs in the Fishing and Agricultural sectors has a negative effect on emission levels of $\mathrm{CO} 2$. In contrary to that, in a detailed and comprehensive study of 54 countries [71] highlighted that there is a reverse causality between the FDIs and the $\mathrm{CO}_{2}$, and the only exception to these results are the Europe and North Asia. Considering these contradictory findings in the existing literatures, it is the need of the time to conduct a detailed study to consider the regional - level data (considering the similarities between the countries in the region), as well as the country - level (Considering the heterogeneities among the countries) to see their differential effects on the $\mathrm{FDI}$ and $\mathrm{CO}_{2}$ relationships. Hence, we posit;

\section{H1. Asian countries with a higher level of FDI have a low level of Environmental Degradation}

\section{FDI and Financial Development}

It is a famous marvel that an increased level of FDI will result in an effective FD system [72]. Theoretically, the nexus between the foreign direct inflow and the FD has been analyzed extensively in the early 1980s, for example, [73] examined the role of the FD of the country to encourage the FDI. They demonstrated and concluded that the antecedents of the FDIs are not related to the FD level of the country instead it is the necessary condition, not the sufficient one. As there are some other factors that are to be considered while assessing the effects of the FD levels of the country and the foreign direct inflows it receives. They further argued that the FD system is necessary but not a sufficient condition for a country to encourage foreign investment in the new technologies. It is also important to consider the financial liberalization while considering the role of the FD in attracting the FDI flows. However, the presence of financial liberalization limits the role of FD to attract more FDI inflows. Nevertheless, the studies abound, which established the positive relationships between the FD of the country and the FDIs it receives [36, 74]. These results imply that the more the financial markets are stable in the economy more are the more chances they received the FDIs to augment their EG while capitalizing on the prevalence of the strong financial markets indigenously.

There is an important and long debate on the role of the institutions in the performance of the financial markets and the EG of the country. For example, [75] argued that the institutions and the financial markets 
work hand to hand in the betterment of the economy, and emphasized on the role of the institutions, which ensures the performance of the financial markets. Similarly, [76] exhibited through a cross-country analysis, that FDIs affect positively the certain components of economic freedom, but not all of them. While considering these arguments, we considered thoroughly the roles of the other institutions such as the political risks which could be the important factor in affecting the relationship between the FD and the FDIs of any country. This could be due to the political instability which creates more uncertainty in the country and would be doubting the continuation of the policies of the incumbent governments. The literature is abundant with the cross-country research which are based on the data available internationally particularly about the impact of the policy-related factors such as the intellectual property protection (IPP), the prevalent corruption situations and both the institutional and non-institutional uncertainties posed to the country, on the FDI inflows [77] [78].

In addition, further numerous scholars have considered the effects of the autonomous associations on the FDI inflows, which is diverse in nature, for example, one strand of thoughts showed that the association between the FDI and the democratic institutions is positive [72, 79, 80]. Li and Resnick, [81] argued that though democratic rights have an indirect positive effect on the FDI inflows which could be attributed to the improvement in a specific dimension of the institutional improvements, particularly, by improving the property rights protection prevailing in the country, in these situations the direct impact on FDI is negative. Furthermore, political (in)stability like government (in)stability, rule of law, absence of the internal and the external conflicts, citizen's basic democratic rights and an efficient law and order system, all together affects the FDI inflows [72]. They further exhibited that the investors willing to invest their capitals are always susceptible to the un-anticipated variations in the political steadiness of a nation, these uncertainties and the un-anticipated changes in the national and international relations of the developing economies are very prominent. Although the developed countries are reasonably more stable as compared to the developing countries, the former still expect some other factors which could affect the FDIs [72]. In these circumstances, the multi-disciplinary studies are more instructive and useful to consider. For example, according to law and finance-related literature, the institutions which are a source of satisfaction for the investors are considered more effective to predict the FDI, such as those institutions which provide investors a sense of protection have been proved crucial for FD of the economies because they attract more FDIs. According to Roe and Siegel [82], political stability shows a crucial role and major role in influential the country's capacity to develop and prosper investment protection programs. They further argued that most of the time the politically unstable governments fail to believably obligate to the policies that could encourage and develop any entrepreneurial occupations and the protection of the financial markets. In this backdrop, it is easy to configure the role of the political stability in the studies aiming to examine the causal linkages between the financial markets, FD and the FDI inflows. Since these phenomena are more prevalent in the developing countries, it is very important to consider the developing countries to assess and examine the role of the financial markets, and FD stages on the FDI inflows. Therefore;

\section{H2. Asian countries with a higher level of FDI have a high level of Financial Development}

\section{FDI and Economic Growth}


To have a high EG and stable economic system, countries need sufficient resources, and especially in emerging economies, this goal can be achieved through FDI [37] because internal resources are not enough to boost the EG. Though, in the influential Harrod [83] and Domar [84] growth models, they considered the savings are the sources of the capital accumulation and the EG of the economies. Later on, Rostow [85] supported the view and provided the evidence regarding the claims and exhibited that savings are the essential elements required for the economies to boost their development. However, these savings are quite difficult to be raised in the short term, particularly for underdeveloped economies. In these backdrops, the leading economists from the International Monetary Fund (IMF) and the World Bank have clearly advised these underdeveloped economies to capitalize on the loaning facilities available from the other economies specifically in the form of the portfolio investments, FDIs and the loans. These tools would be used to augment the internal savings which could be helpful in achieving the targeted EG rates determined by the countries, based on their internal resources. The regional leaders aim to develop their respective regions, and in these contexts, they compete for the FDIs through the provision of respective incentives, such as the tax incentives and other subsidies, which could attract the capitals from the international ventures and the international donors [86]. Additionally, emerging countries were enticed into sustaining large foreign obligations, which sort it difficult for them to service and very often resulted in interference by the foreign powers by controlling their most valuable resources. These attributes make these investments not risk free, and sometimes threatens the sovereignty of the developing countries [87-89]. Herzer, Hühne, and Nunnenkamp [39] observed the noticeable inequalities in the developing economies from the FDIs, with causality from the FDIs to inequality. Rationalizing the flow of the funds from the developed economies to the developing economies, the new-classical economists $[90,91]$ argued that while considering the diminishing returns on the capitals in the developing economies would suggest the higher returns on the capitals, which further strengthen the arguments of the flow of the capital from the developed to the underdeveloped economies. This flow of capital would support the latter is catching up on the pace of the growth. These arguments further motivated the developing economies to attract more FDI to boost their economies. In contrast, the empirical results suggests other way around; such as Abramovitz [92] and Solow [93] demonstrated that the long-run growths are the results of the technological advancement, rather than the financial investment from the foreign sources. In addition, another contradiction was that the argument of the flow of capital from the rich to the poor economies was also overemphasized (e.g., [94, 95]. Neoclassical growth models suggested that the technological transfusion from foreign countries in the form of the FDI and other investments is the key to the development of the under-developed economies [96-99]. The proponents of the endogenous growth theory such as [100-102] challenged the exogenous growth theory of the Solow-Swan, by developing their arguments in favor of FDI, which could also be justified as a tool to transfer the technology from the developed to the under-developed economies, thereby, not only emphasizing the role of the technology, but also highlighting the importance of the FDI in supporting the transfer of the technology. The technology and the FDIs are the important factors in the improvement of the domestic productivity of the country [38]. In these backdrops, it is still debatable whether the countries who are getting the FDIs really experience the proportionate amount of the technology transfer or not. There are studies, which still could not provide any proof of the progressive association between the FDI and the domestic total factor production of the sample of more than 100 countries (for example, $[37,103]$. Therefore; 


\section{Financial Development and Environmental Degradation}

An effective FD can help the nation with a clean and quality environment [104]. Hence, it is very important for a country to enjoy the fully functional and optimal financial market in order to achieve the desired level of environmental performance [105]. However, sometimes, overemphasizing the financial markets only may overshadow the other important dimension of the overall economy, such as environmental and ecological development. It is unequivocally accepted across the globe, that there is a tradeoff between the EG and the energy consumption. Similarly, any form of investment and growth would result in high levels of energy consumption (for example see; [106-108]. However, further simplification of the situation would consider the emission of environmentally hazardous gases such as the $\mathrm{CO}_{2}$ while consuming natural energy. Different streams of research have considered these relationships between the FD of a country and the emission level of $\mathrm{CO}_{2}$ as a result of the energy consumption.

The first stream of research argues that the FD negatively affecting ED, such as the former is improving the environment by controlling the $\mathrm{CO}_{2}$ emission levels. While considering the BRICs countries Tamazian et al [109] examined the effects of $\mathrm{FD}$ and the $\mathrm{EG}$ on the emission levels of $\mathrm{CO}_{2}$ and demonstrated that there are fewer levels of the $\mathrm{CO}_{2}$ emission in the developed countries as compared to the less developed countries. In a similar vein, Tamazian and Rao [110] examined the effects of financial liberalization (a different economic phenomena than the FD), and found that in 24 transition economies financial liberalization plays a very important role in improving the quality of the environment by decreasing the emission levels of $\mathrm{CO}_{2}$, as compared to those who have no or less financial liberalization. Similarly, in China, there is a negative effect of the FD on the levels of $\mathrm{CO}_{2}$ emission [111]. Shahbaz et al. [112] exhibited the negative relationship between the FD and the $\mathrm{CO}_{2}$ emission in Malaysia and South Africa. In Pakistan, the negative relationship between the $\mathrm{FD}$ and the $\mathrm{CO}_{2}$ emission is observed only during the periods of the high levels of liberalization and FD [59]. In the latest study, the top-performing countries in the list of the Renewable Energy Attractiveness Index (REATI) exhibited a positive association between the FD levels and the environmental quality [113].

The second stream of research supports the idea of the adverse effects of the FD on environmental quality. They propagate that the FD causes more energy consumption, which ultimately results in the emission of high levels of $\mathrm{CO}_{2}$, which deteriorates the overall environment. For example, multiple studies exhibited and supported this assertion in different countries, such as in China [114] in Indonesia [105] however, taking different indicators of the FD, the results are different, such as while taking the bank-based development vs stock market - based financial market indicators. The bank-based FD, as well as stock market - based FD, have a negative association between the FD and the ED $[115,116]$. However, more recently, Salahuddin et al., [104] demonstrated a significant positive association between FDI, FD and $\mathrm{CO}_{2}$ emission in Kuwait.

Finally, the third stream of research which is indifferent as far as the association between the FD and the environmental deterioration is concerned and exhibited no association between these two. For instance, Ozturk and Acaravci [117] while examining the association between FD and the $\mathrm{CO}_{2}$ emission exhibited no 
association in the long-run in Turkey. Similarly, in 12 MENA countries, the association between these two is neutral [118], however, for $6 \mathrm{GCC}$ countries, the results are mixed for association between the FD and the $\mathrm{CO}_{2}$ emission levels [119]- such as the association is positive in Saudi Arabia, Kuwait, Bahrain and Oman; while there is negative association between FD and $\mathrm{CO}_{2}$ emission in Qatar and the United Arab Emirates.

Furthermore, in a single country study, such as only focusing on UAE, there is an inverted-U association [120]. However in the developed economies, the results are mixed, for example, in the 27 European Union countries, the results display not connection between the energy costs levels and the FD; while using the bank index, the association between the FD and the $\mathrm{CO}_{2}$ emission exhibited an inverted- $U$ shaped association between them, however, insignificant relationship between them when they are assessed based on the stock-index [121]. These results imply that not only the measurement of the FD is important while studying the effects of the FD on the environment, but also the country level heterogeneous characteristics are also important, which should be considered while assessing the association between the FD and the $\mathrm{CO}_{2}$ emission levels. Hence;

\section{H4. Asian countries with a higher level of FD have a low level of Environmental Degradation}

\section{Economic Growth and Degradation of the Environment}

A country needs an effective EG model that is required to degrade environmental pollution [122]. There are myriad of the measurement tools available to gauge the EG of a country, but what is very often used, is the changes in the GDP, which is the gross domestic product of the country with reference to the previous year. Regardless of the measurement variation, the uniqueness lies in the phenomena is that it is a very important concern of the economies, particularly the macroeconomic planning and policy-making after the emergence of the capitalist economies after World War-II see, [123] for details. Policymakers are aimed to achieve consistent improvement in the GDP over time, but there are ways some costs associated with everything to be achieved in the international phenomena, and the GDP is no exception. Such as the consistent growth in the GDP may bring some negative changes to the overall situation of the country. For example, with more development which is the cornerstone of the GDP growth, there are more energy consumption and more natural resources consumption which creates an imbalance in the natural environment of the country. A major concern of the environmentalists is the environmental deterioration of the country, which is overshadowed by the GDP growth. Empirical evidence has abounded which examined the association between the GDP growth and the environmental deterioration of a country by capitalizing on the Environment Kuznets Curve (EKC) [54]. Simon Kutz [54] argued that there is an inverted U shaped relationship between the GDP growth and the environmental deterioration, such as the GDP growth would deteriorates the environment in the long run, however, after reaching the peak of the GDP growth, which is very often gauged in terms of the per capita real GDP, it improves the environment by reducing the ED. This inverted $U$ shaped relationship between the GDP growth and the environmental deterioration makes this association too complex to grasp it easily. This ambiguity is evident from the existing results on the relationship between the two variables, such as Apergis [52] examined the association between the per capita GDP growth and the $\mathrm{CO}_{2}$ emission levels in 15 countries in a single study. The results satisfy the prevalence of relationships just like the environmental Kuznets Curve, while others gave some straightforward results. A single study incorporating the data from Brazil, China, Egypt, Japan, Nigeria, Mexico, South Africa and South 
Korea, showed that only South Korea and Japan showed the environmental Kuznets Curve. Further to that inverted U shaped curve, some of the countries exhibited an N-shaped curve between the GDP growth and the emission level of $\mathrm{CO}_{2}$. These differences in the relationships can be related to the different development stages of these countries, since they are heterogeneous as far as their economic development and GDP growth is concerned. Similarly, in a 43-country panel study (which included Middle Eastern and ASEAN countries) exhibited a positive association between the income levels of the household and the $\mathrm{CO}_{2}$ emission, however some countries showed totally different results despite the fact all of them were developing countries. The factors which contributes to the heterogeneity in the relationships between the GDP in the $\mathrm{CO}_{2}$ emission needs to be explored further in order to guide the policy makers in the right directions while formulating the policies for the achievement of the targets of the EG.

There are different comparative studies that considered the different sets of countries to see the relationships between the GDP and $\mathrm{CO}_{2}$ emission from the perspective of the different income levels. One such study considered 26 OECD economies which were characterized as having high levels of income on the one hand and another group of 52 emerging economies, which were having a low level of incomes [44]. The results showed both the $\mathrm{N}$-shaped and inverted $\mathrm{N}$-shaped relationships between GDP growth and environmental deterioration. These results contradict the EKC hypothesis which is established by other authors in other sets of countries. These results suggest that environmental quality and conditions are not solely relying on the GDP growth of the countries, besides the differences in the countries warrants more insights into the relationships. The heterogeneity prevails in both scenarios such as i) when countries' development stages are different, ii) when the countries' development stages are not different. For example, a 27 advanced country panel study exhibited an inverted U-shaped relationship between the GDP growth and the environmental deterioration [124], while studies on the Chinese Region [45] and the US [125] showed mixed results about the establishing the environmental Kuznets Curve hypothesis. Considering all these disparities and the ambiguities in the association between the GDP growth, FD and the environmental deterioration, whether these differences prevail in the different groups of countries, such as developing versus developed countries, or are there some other factors which make them exhibit different pattern of relationship between the GDP growth and the environmental deterioration. In this context, the comparative studies while taking the countries in groups based on the developing and developed countries groups, which could ascertain the between-group and within-group differences in the relationship between the GDP growth and the environmental deterioration hypotheses. Hence,

\section{H5. Asian countries with high EG growth have a low level of Environmental Degradation}

\section{The mediating role of FD and EG}

FDI is the cornerstone of the EG of any country regardless of its development stage. FDI is undoubtedly a very important factor in the sustainability of developing countries. However, there may be some hazards caused by these FDIs, which could be more than the benefits it gives to any economy. Literature has claimed that FD is a significant predictor of ED [31]. However, in the discussion, both negative[33,34] and positive [28-30] results are discussed. It can give alarming signals that the relationship between FDI and ED is questionable. Soumaré and Tchana Tchana [55], for instance also claimed that care is needed to test and 
unleash the importance of FDI in financial market development and EG because it is ambiguous how it assists an economy in its development. In other words, considering the fragmented results (negative and positive), we perceive the relationship is something indirect. Taking the assumptions of $\mathrm{Hu}$, Wang, Lian and Huang [126] who claimed that environmental regulation can affect the relationship between FDI and green technological progress. Similarly, Lan, Kakinaka and Huang [127] argued that the link between FDI and environmental pollution is affected in the presence of human capital. Furthermore, as Opoku, Ibrahim and Sare [128] claimed that FDI is a significant positive driver of EG that in turn can reduce ED [44, 123]. Favoring this notion, Kalai and Zghidi [129] claimed that FDI has a long-lasting favorable influence on EG and development that is beneficial for ED [37]. Consequently, FDI is very essential for high EG and development [130] and such types of development can in turn significantly attenuate environmental pollution, environmental problems and ED $[59,111]$. Additionally, an increased level of FDI will improve the distribution of private credit in a country. There will be adequate financial resources for business firms to participate in environmental activities. Because the lack of financial resources hampers the participation of business industries in environmental activities [131]. Indeed, adequate financial resources are very fruitful for venture operational activities. If a venture receives satisfactory finance and capital in a country (e.g. from government, FDI or financial institutions), it will smooth its operational activities and will able to achieve sustainable competitive position [132] and in turn, there will be a strong possibility to participate in the environmental activities. As pointed out by Dutta and Roy [133], the inflow of FDI helps the economy to increase the ratio of public credit to the industrial sector. It reveals that FDI is a significant predictor of FD. Additionally, Otchere, Soumare and Yourougou [134] revealed that FDI plays a backbone role in the productive sector and improves the production level of various industries because they receive adequate financial resources. In turn, FD significantly improves environmental quality [135]. Sirag, SidAhmed and Ali [136] claimed that the relationship between FDI and economic performance is affected by FD in many nations. Hence, there will be effective strategies for the inflow of FDI in order to spur FD and EG because both are very crucial for environmental quality [13]. So it is perceived that FDI will not directly influence ED but it will first enhance FD and EG that in turn will significantly influence ED.

H6. The path between FDI and ED is mediated by FD in Asian countries.

H7. The path between FDI and ED is mediated by EG in Asian countries.

\section{Methodology}

\section{Data and Sample}

We used secondary data to test the relationship between FDI, EG, FD and ED in the Asian countries. The reason for choosing the specific Asian countries is the fragmented results scrutinized by numerous studies. Moreover, they face serious environmental pollution problems because of the lack of policies for environmental practices. We gathered data from the World Bank Indicators (WBI) from 1980-2018). The variables of the study are discussed below.

FDI: It is the ratio for investment by foreign countries in a host country. The investment is done for several reasons including environmental safety and trade.

Page 13/31 
Environmental Degradation: Normally considered as Carbon Emission $\mathrm{CO}^{2}$ it is the logarithm of carbon dioxide emissions. The above model indicates ED or $\mathrm{CO} 2$ that are considered the most used measure in existing literature for ED (see [105, 137].

Financial Development: For FD, the proxies; domestic credit, liquid liability and private credit are mostly used in the literature $[108,118]$. However, most of the studies suggested the domestic credit as a useful and valid proxy for FD in Asian regions $[138,139]$. In other words, the proxy used for FD measured is the annual flow of domestic credit to the private sector as a ratio of GDP and is one of the most extensively used indicators in the present literature see $[138,139]$ among others. It indicates the amount of credit abstracted by financial intermediation from savers to the private sectors. Several studies have used the measures when they tried to examine the relationship between FD and environmental issues $[105,109,111]$. Therefore, we relied on this proxy to measure the FD.

Economic Growth: Proxy uses for GDP e.g. in constant 2010 US \$.

\section{Model Specification}

The algebraic model of the study is presented below:

\begin{tabular}{|c|c|c|}
\hline Model & Explanation & Path \\
\hline Model 1 & $\mathrm{CO} 2=\mathrm{B} 0+\mathrm{FDI}+$ Control variables $+\bigotimes \mathrm{t}$ & FDI à ED \\
\hline Model 2 & 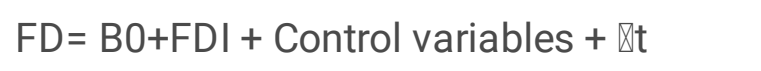 & FDI à FD \\
\hline Model 3 & $\mathrm{EG}=\mathrm{B} 0+\mathrm{FDI}+$ Control variables $+\varangle \mathrm{t}$ & FDI à EG \\
\hline Model 4 & $\mathrm{CO} 2=\mathrm{B} 0+\mathrm{FD}+\mathrm{EG}+$ Control variables $+\triangle \mathrm{t}$ & FD+EGàED \\
\hline Model 5 & $\mathrm{CO} 2=\mathrm{B} 0+\mathrm{FDI}+\mathrm{FD}+$ Control variables $+\triangle \mathrm{t}$ & FDlàFDàED \\
\hline Model 6 & $\mathrm{CO} 2=\mathrm{B} 0+\mathrm{FDI}+\mathrm{EG}+$ Control variables $+\nabla \mathrm{t}$ & FDlàEGàED \\
\hline
\end{tabular}

\section{Data Analysis}

\section{Descriptive statistics}

We performed descriptive statistics in SPSS The results of descriptive analysis shows (see table 2) that EG has the highest Mean value 27.17 while FD has the lowest 1.57. EG has also the highest SD 9.93 while FD has the lowest SD 0.42. Additionally, the normality test shows that the distribution of data is normal as none of the constructed value exceeds the threshold value of \pm 2 for both skewness and kurtosis as per the suggestion of [140]. Furthermore to check the problem of Multicollinearity in the data we executed the Variance Inflation Factor (VIF) in Stata. The results of the VIF were reported in Table 2. We confirmed the absence of multicollinearity in the data set as none of the factors has a VIF value above 10 [141].

Table 2 Descriptive statistic 


\begin{tabular}{|llllll|}
\hline Variables & Mean & Std.Deviation & Skewness & Kurtosis & VIF \\
\hline ED & 2.09 & 4.029 & 1.873 & 1.001 & - \\
FDI & 9.309 & 2.774 & -1.753 & 1.221 & 1.39 \\
\hline FD & 1.527 & 0.422 & 1.302 & 1.343 & 2.64 \\
ECG & 27.176 & 9.930 & 0.670 & 1.443 & 2.08 \\
\hline
\end{tabular}

\section{Correlation analysis}

To obtain the evidence on the relationship among variables. We estimate the correlations coefficient. The correlation estimation with the $p$-value is given in Table 3 . The results of correlation coefficient indicates that FDI and FD are significantly positively related to ED ( $r=0.211, p<0.05,(r=0.112, p<0.05)$, while ECG is insignificantly related with $E D(r=0.0642, p>0.05)$. Furthermore, there is a significant positive association between FDI and ECG $(r=0.0261, p<0.05)$. The relationship between FDI and FD is found insignificant $(r=-0.017, p>0.05)$. The correlation table supported our argument about the absence of multicollinearity as scholars such as [142] suggested the potential collinearity problem exists if the correlation coefficient is more than 0.8 however in this the highest values are 0.26 among the Df and ECG.

\section{Table 3. Correlations}

\begin{tabular}{|c|c|c|c|c|c|c|c|c|}
\hline Variables & PG & GCF & INDG & TOP & FDI & FD & ECG & ED \\
\hline PG & 1.000 & & & & & & & \\
\hline GCF & $0.309 * \star \star$ & 1.000 & & & & & & \\
\hline INDG & 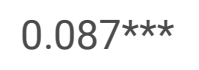 & $0.553^{\star \star \star}$ & 1.000 & & & & & \\
\hline TOP & $0.158 * \star \star$ & $-0.260 * \star \star *$ & $-0.340 * * *$ & 1.000 & & & & \\
\hline FDI & -0.045 & $0.394^{* * \star}$ & $0.595^{\star \star \star}$ & $-0.674 * \star \star$ & 1.000 & & & \\
\hline FD & $0.163^{\star \star \star}$ & $0.523^{\star \star \star}$ & $0.1140 * \star$ & $0.0073^{\star * *}$ & -0.017 & 1.000 & & \\
\hline ECG & $-0.117 * \star \star$ & 0.0696 & $0.1838 * \star \star$ & $-0.209 * \star \star$ & $0.261^{\star \star \star}$ & $0.133^{\star \star \star}$ & 1.000 & \\
\hline ED & 0.0818 & $0.458^{* \star *}$ & $0.679 * * \star$ & $-0.077^{\star *}$ & $0.211 * * \star$ & $0.112^{\star \star *}$ & 0.0642 & 1.000 \\
\hline
\end{tabular}

\section{Panel unit root test results}

In spite of the fact that the mostly used test is the unit root test in economic and business studies. Moreover, the panel unit root test has become significantly popular among scholars due to it's over other tests that are used for normal time series unit root. In this, specifically the Im, pesaran will be used in this study. Those tests are used to derive a panel specific result. The unit root test specifies a separate ADF regression for each cross-section. The test has the following null and alternative hypotheses.

HO: The variable is not stationary or got unit root. 
$\mathrm{H} 1$ : variable is stationary

Table 4 indicates that the unit root test outcome and clearly shows that most of the level of the variables are not stationary, but only the population growth variable is stationary. However, the findings revealed that the variables are stationary at the first variance refusing the null hypothesis representing that the variables exists a panel unit root.

Table 4. Panel unit root test result

\begin{tabular}{|c|c|c|c|c|}
\hline \multirow[t]{2}{*}{ Variable } & \multicolumn{2}{|l|}{ level } & \multicolumn{2}{|l|}{$\begin{array}{l}\text { First } \\
\text { difference }\end{array}$} \\
\hline & Intercept & $\begin{array}{l}\text { Intercept and } \\
\text { trend }\end{array}$ & Intercept & $\begin{array}{l}\text { Intercept and } \\
\text { trend }\end{array}$ \\
\hline \multicolumn{5}{|l|}{ Im, Pesaran and Shin W-stat } \\
\hline $\mathrm{Co} 2$ & 6.7015 & 1.1994 & -12.3561 *** & $-10.9573^{\star \star \star}$ \\
\hline FDI & 7.9930 & 2.0916 & -10.0288 & $-8.6501^{\star \star \star}$ \\
\hline Financial Development & 6.8983 & 1.5673 & $-11.1567 * \star \star$ & $-9.2624 * \star \star$ \\
\hline $\begin{array}{l}\text { Economic Growth constant } 2010 \\
\text { US\$) }\end{array}$ & 5.4758 & 3.324 & $-9.8675^{\star \star \star}$ & $-8.3831^{\star \star \star}$ \\
\hline Gross Capital Formation & -1.0858 & 0.0488 & -13.4169 & $-11.4281^{\star \star \star}$ \\
\hline $\begin{array}{l}\text { Industrial Growth Percentage of } \\
\text { GDP }\end{array}$ & -1.5952 & 1.1325 & $-12.9549 \star \star \star$ & $-10.9923-$ \\
\hline Trade openness & 1.5283 & 3.5747 & $-9.7625^{\star \star \star}$ & 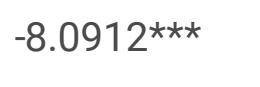 \\
\hline Population growth & 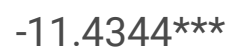 & 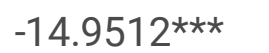 & $-17.0592 * \star \star$ & -16.0264 *** \\
\hline
\end{tabular}

Note: the unit root test was applied with individual tendencies and intercept for each variable, the optimal lag length were designated routinely using the Schwarzinformation criteria,nnnindicates significance at $1 \%$ level.U. Al-mulali, C.N. Binti Che Sab / Renewable and Sustainable Energy Reviews 16 (2012) 436543694367

\section{The Assumptions of OLS and Selection of a model; Pooled OLS, Random Effect and Fixed Effect Model}

Apart from collinearity and stationarity, we also examined other important assumptions such as autocorrelation and heteroscedasticity. For autocorrelation, we used the Wooldridge test. The result shows that P-value is 0.3722 which supporting the acceptance of the null hypothesis of no first-order serial correlation and determined that our data is not distrusted by autocorrelation. Similarly, to examine the potential heteroscedasticity problem, we used the Modified Wald test, Breusch, and pagan Lagrangian multiplier test. Heteroscedasticity is existed when a p value is less than 0.05 (significant). In contrast, an insignificant $p$ value (above 0.05 ) illustrates the absence of heteroscedasticity. In the present research, in both cases (Modified Wald test and Breusch and Pagan Lagrangian multiplier test), however, in our analysis, 
all the factors displayed an insignificant value $p$ value greater than 0.05 and thus revealing the absence of heteroscedasticity.

To identify whether pooled regression, fixed effect or random effect model is appropriate, we applied two different tests such B-P-LM test and the Hausman test. We Applied the B-P-LM test to decide whether the pooled or random-effect model is appropriate. The null hypothesis of Breush-Pagan Lagrange multiplier test is individual specific or time-specific error variance components are equal to zero whereas the P-value associated with the chi-square statistics is zero. Thus, we are unable to oppose the null hypothesis and consequently, we find that individual specific or time-specific error variance apparatuses are equal zero, suggesting that the random effect model is appropriate. We further applied the Hausman test for the goal to choose the random or fixed-effect model. The null hypothesis of the Hausman test is that the random effect model is proper for testing. Hence, if the $P$ value received from the Hausman test is greater than 0.05 , we should favor the null hypothesis and will select the random effect model. In the present research, the $p$ value is significant (0.0051), hence we opposed the null hypothesis and selected the fixed effect model in this research.

\section{Table 5 Choosing Among Pooled OLS, Random Effect and Fixed Effect Model}

\begin{tabular}{|c|c|c|}
\hline Fixed effect Model (F-Test) & $\begin{array}{l}\text { Random Effect (B-P-LM } \\
\text { Test) }\end{array}$ & Our Selection \\
\hline \multirow{4}{*}{$\begin{array}{l}\text { Ho is not rejected } \\
\text { (No fixed effect) } \\
\text { F test that all u_i }=0: F(17,497)= \\
80.58\end{array}$} & Ho is not rejected & \multirow[t]{4}{*}{ Pooled OLS } \\
\hline & (No random effect) & \\
\hline & Chi2 $=2720$ & \\
\hline & $P$-value $=0.000$ & \\
\hline Ho is rejected & Ho is not rejected & \multirow[t]{2}{*}{ Fixed effect model } \\
\hline (fixed effect) & (No random effect) & \\
\hline Ho is not rejected & Ho is not rejected & \multirow[t]{2}{*}{ Random effect model } \\
\hline (No fixed effect) & (random effect) & \\
\hline Ho is rejected & Ho is rejected & \multirow{2}{*}{$\begin{array}{l}\text { Hausman test select which model is } \\
\text { appropriate }\end{array}$} \\
\hline ( fixed effect) & (random effect) & \\
\hline
\end{tabular}

To identify whether pooled regression, fixed-effects model, random effect model is appropriate we apply the B-P-LM test on the random effect model to check wither random effect is appropriate or not and F-test use to check to wither Fixed effect model are appropriate.

F-test value and its P-value 
F-test basically tells us to wither there is an individual specific effect or not. We test the following null and alternative hypotheses

Ho: Individual specific effect is equal to zero.

$H 1$ : Individual specific effect is not equal to zero.

It is clear from Table 3 that F-test is equal to all $u_{-} i=0$ its mean that all individual-specific effect is equal to zero and it's p-value $=0.0000$. so it's mean that on the basis of the fixed-effect model and on the basis of Ftest value we reject the alternative hypothesis that there is not individual specific effect and accept the null hypothesis. so that is in the favorer of the fixed-effect model.

\section{The Breusch- Pagan LM Test (B-P-LM Test).}

The Breusch-Pagan Lagrange multiplier test examines if any random effect exists or not.

We test has the following null and alternative hypotheses.

Ho: Individual specific or time specific error variance components are equal zero.

H1: Individual specific or time specific error variance components are not equal to zero.

Table 5 shows that the p-values associated with the chi-square statistics are zero. Thus we cannot reject the null hypothesis. Therefore, we find that the Individual specific or time-specific error variance components are equal zero, suggesting that the random effect model is appropriate

\section{Testing Hypotheses}

To do the mediation analysis, we performed four steps method suggested by Baron and Kenny [143]that have discussed in Table 6. So to follow the Baron and Kenny [143] procedure of mediation in first model IV was regressed on DV. The results of model 1 (see Table ) show that FDI has a negatively significant influence on ED $(\beta=-0.448, p<0.05)$ which favored $H 1$. In the second and third models, IV was regressed on the mediator. The result of model 2 and model 3 reveals that FDI has significant negative impact on FD ( $\beta=$ $-0.024, p<0.05)$ and significant positive influence on ECG $(\beta=0.802, p<0.05)$ which did not support $\mathrm{H} 2$ but supported $\mathrm{H} 3$ respectively. In the fourth model, the mediators were regressed on DV. The result of model 4 indicates that both mediators FD and ECG have a significant negative influence on ED $(\beta=-0.799, p<0.05$ \& $\beta=-0.636, \mathrm{p}<0.05)$ which supported $\mathrm{H} 4$ and $\mathrm{H} 5$.

In the $5^{\text {th }}$ model, the mediating role of FD was investigated between FDI and ED. The results of portrayed that the indirect influence of FDI on ED is significant in presence of FD $(\beta=-0.529, p<0.05)$ but the direct relationship also remains significant $(\beta=-0.389, p<0.05)$ which partially supported $\mathrm{H6}$. It reveals that FD partially mediates the relationship between FDI and ED. $R$ squire value shows a $59 \%$ variation in ED that is explained by FDI when the mediating role played by FD. In the $6^{\text {th }}$ model, the mediating role of ECG was investigated between FDI and ED. The results depicted that the indirect influence of FDI on ED is insignificant in presence of ECG $(\beta=-0.011, p>0.05)$ but the direct relationship has remained significant $(\beta=-0.503, p<$ 
0.05) which does not support H7. It reveals that ECG does not mediate the relationship between FDI and ED. $\mathrm{R}$ squire value shows a $57 \%$ variation in ED that is explained by FDI when the mediating role played by ECG.

Table 6. Hypotheses Testing

\begin{tabular}{|c|c|c|c|c|c|c|}
\hline & Model 1 & Model 2 & Model 3 & Model 4 & Model 5 & Model-6 \\
\hline & IV-DV & IV-MED & IV-MED & MED-DV & IV-MED-DV & IV-MED-DV \\
\hline \multicolumn{7}{|c|}{ Control variables } \\
\hline PG & 0.021 & $0.063^{\star \star \star}$ & $0.966^{\star \star}$ & $-0.858^{\star \star \star}$ & $-0.692^{\star \star \star}$ & -0.210 \\
\hline GFCF & $0.043^{* \star *}$ & 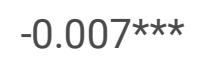 & $-0.365^{\star \star \star}$ & $0.029 *$ & $-0.073^{\star \star \star}$ & $-0.246^{\star *}$ \\
\hline IG GDP & $0.215^{\star \star \star}$ & 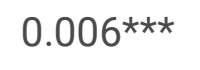 & $0.328 * \star \star$ & $0.213^{\star \star \star}$ & $0.184^{\star \star \star}$ & 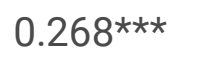 \\
\hline TO & 0.066 & $1.598 * \star \star$ & $0.328 * \star \star$ & 1.5811 & -1.705 & 1.387 \\
\hline \multicolumn{7}{|c|}{ Ind variable } \\
\hline FDI & $-0.448^{\star \star \star}$ & $-0.024^{\star \star}$ & $0.802^{\star \star \star}$ & & $-0.389 * \star \star$ & -0.503 \\
\hline \multicolumn{7}{|c|}{ Mediators } \\
\hline FD & & & & $-0.799 \star \star$ & $-0.523^{\star \star}$ & \\
\hline ECG & & & & $-0.636^{\star \star \star}$ & & -0.011 \\
\hline $\mathrm{R}^{2}$ & 0.55 & 0.83 & 0.54 & 0.58 & 0.59 & 0.57 \\
\hline F value & 320 & 495 & 39.53 & 93.52 & 106 & 100.64 \\
\hline Prob F & 0.000 & 0.000 & 0.000 & 0.000 & 0.000 & 0.000 \\
\hline
\end{tabular}

Dependent variable $=\mathrm{ED}$

Table 7. Hypotheses Remarks

\begin{tabular}{|c|c|c|c|}
\hline Hypotheses & Paths & Proposed & Our results \\
\hline $\mathrm{H} 1$ & FDI à ED & -Significant & Significant \\
\hline $\mathrm{H} 2$ & FDI àFD & + Significant & Significant \\
\hline H3 & FDI àEG & + Significant & + Significant \\
\hline $\mathrm{H} 4$ & FD àED & Significant & Significant \\
\hline H5 & EG àED & Significant & Significant \\
\hline H6 & FDI àFD àED & Significant & Significant \\
\hline H7 & FDI àEG àED & Significant & Insignificant \\
\hline
\end{tabular}




\section{Discussion And Conclusion}

This study used the secondary data between 1980-2018 of Asian countries (Bangladesh, Bhutan, Brunei, China, Fuji, India, Indonesia, Kiribati, Leo, Malaysia, Maldives, Magnolia, Myanmar, Nepal, Pupa New, Philippine, Solomon, Samoa, Sri Lanka, Thailand and Tonga) to unleash the importance of FDI in FD, EG that results a low level of ED. It is doubtless that the paths between FDI, FD, EG and ED have been tested extensively in growing and developed markets $[8-15,18,19]$. However, studies are still ambiguous either FDI has negative or positive as well as direct or indirect influence on ED across the globe. However, despite the elusive outputs, the contributions of the prior studies should not be undervalued in terms of theories and practice. However, referring to the fragmented insights and consequences, and especially the mediating role of FD and EG between FDI and ED that has been received minor attention in Asian economies, this study uses data of Asian economies to unpack how FDI plays a key role in the improvement of FD and EG that results in high environmental quality. This research tests two major theories; Kuznets curve hypothesis and Pollution haven hypothesis [42]. For instance, The Kuznets curve hypothesis describes that as the economy grows, market forces increase and then gradually decline due to economic inequality. One of the major explanations of this theory is that when foreign investors perceive a high growth in an economy, they tend to invest in the industrial sector that also benefits environmental activities in the host nation. Our results partially support this theory because we found that FDI is crucial for EG but in results, it does not improve environmental quality. However, our study favors the pollution heaven hypothesis, which displays that when large firms aim to set up their operational and environmental activities in other markets, they need cheap resources and support [42]. Our results confirm that FDI provides advantages to the host firms to settle their business activities and to participate in environmental activities.

Our study revealed that FDI has a significant negative influence on ED in Asian economies. Our results favor some studies as well as also oppose many studies in the context. For instance, our study supports Shahbaz et al., [105] who revealed that an increased level of FDI can result in environmental quality and a low level of environmental pollution. Similarly, Hu, Wang, Lian and Huang, [126] also tested the prominence of FDI in environmental activities and revealed that Asian countries get many advantages of FDI for environmental and sustainability practices. However, on the other hand, our results do not match Solarin and Al-Mulali [57] who claimed that FDI has not a significant influence on ED especially in developed economies because of dirty pollution, it is difficult to enhance the environmental cleanness. Surprisingly, our findings revealed that FDI negatively influences FD in the Asian regions. Our findings partially support McKinnon and Shaw [144] who claimed that FDI does not significantly improve FD in a country due to several unfavorable conditions. Therefore, a country needs strong financial liberalization policies to boost the FDI inflow in a better way that configure FD. Dutta and Roy [133] also claimed that sometimes due to the political instability, a country's FD system is not performing satisfactorily despite having sufficient FDI. Favoring the arguments, we argue that political conditions in the Asian regions are not stable and not effective. However, the hypothesis for a significant positive relationship between FDI and EG is supported by this study. The findings confirm that the economy in emerging and Asian countries can be improved by increasing the inflow of FDI. Our results further confirmed that FD and EG significantly negatively influence ED in the Asian regions. It scrutinizes that effective FD and high EG are significant predictors of environmental activities and sustainability in the Asian regions. Our findings support several studies that have scrutinized a significant negative association 
between FD and ED $[105,111,115,116]$ and a significant negative association between EG and ED [145147]. These studies have inspected that a country with stable FD and high EG can reduce environmental pollution.

Our study displays a partial mediating role of FD between FDI and ED. It is because the inflow of the FDI is mainly used from ED rather first cross and distributed in the industrial sector. Partially supporting Otchere, Soumaré and Yourougou [134] who stated that FDI is very crucial for EG and stability that in turn results from the environmental performance. Our study shows that FDI equally improves FD and environmental quality in the Asian regions. However, our research depicted that EG is not a significant mediator between FDI and ED in the Asian regions. Unlike Shahbaz, Nasir and Roubaud, [135] who claimed that FDI significantly improves economic propensity and development that is vital for sustainability and environmental quality. Our study states that EG is not a significant mediator but FDI directly influences ED in the Asian regions.

\section{Policy and Practice Implications}

Our study suggests several worthwhile implications for policymakers and practitioners who are responsible for making policies related to FDI and environmental in developing and developed markets. Our study revealed that FDI significantly enhances environmental quality and degrade environmental pollution. Sustainability practices and environmental performance need sufficient financial resources. Therefore, policymakers should encourage and promote the inflow of FDI in the Asian regions to enhance environmental performance. However, our research displays that FDI has a negative significant influence on FD in Asian economies. Therefore, our study strongly recommends policymakers to investigate the negative influence of FDI on FD. This may be the wrong distribution of financial resources in the Asian regions. It is also suggested for policymakers that the distribution of FDI should be disconnected from political intervention because it can hamper the financial distribution. Policymakers need to focus on the improvement of FD and EG because both are very crucial for environmental quality and sustainability activities. Our study scrutinized that FD is a partial mediator between FD and ED in the Asian regions. It argues that FDI has a greater influence on ED as compared to FD that can mediate the association. However, our study displays that EG is not a significant mediator between FDI and ED in the Asian regions. It advocates that FDI directly influences ED instead of first improving EG in the Asian regions. Policymakers should investigate the path and should evaluate the strength of the association between FDI, EG and ED in the Asian regions. Alternatively, it posits that if policymakers and economists mainly emphasize ED as compared to EG, they need to encourage and promote the inflow of FDI in the region. The implications are not only constructive for the Asian countries but other neighbor countries and connected regions should also follow it to ensure environmental performance. Since several Asian economies are connected with developed markets in terms of trade and culture. Therefore, the implications can be opted in developed regions to ensure a safe environment, high EG and effective financial system.

\section{Limitations and Signals for Future Studies}

This research assessed an important aspect that has been missed in the existing literature. However, still, there are a few limitations that can be discussed in future research work. The first limitation of this study is to collect evidence from only Asian firms while ignoring developed firms. Hence, it will better to test a model 
on a data set gathered from both emerging and developed firms to generate significant implications. We also suggest conducting a comparative study on the evidence gathered from BRICS, Asian and European economies to unleash the importance of FDI in these nations. We tested only the importance of FDI in FD, EG and ED in this study. Future studies can test the importance of other contemporary factors if they are very useful for ED in the sampled economies. For instance, Haseeb et al.,[148]suggested that information and communication technology improve environmental quality in the era of globalization. Hence, we recommend testing if FD and EG mediate the relationship between technology and ED. Moreover, as pointed out by Saint Akadiri et al., [149] that globalization and emerging consumption play a significant role in environmental sustainability. Hence, these factors can be tested in a model articulates the results in a better way.

\section{Declaration}

Conflict of Interest: There is no conflict of interest in this study.

Funding: This research has not received funding.

Acknowledgement: We are thankful the group members of the lab who help and assisted the authors to complete the research.

Ethics approval and consent to participate: There was no ethical concern with this study because it is an independent study and the researchers have collected data from secondary source. However, the college committee approved the model for conducting research.

Consent for publication: All the authors are agreed to publish the manuscript in the journal

Availability of data and material: Data are available on request

Authors' contributions: All the authors equally contributed to the study.

\section{References}

1. Gorus, M.S. and M. Aslan, Impacts of economic indicators on environmental degradation: evidence from MENA countries. Renewable and Sustainable Energy Reviews, 2019. 103: p. 259-268.

2. Lin, C. and S. Nakamura, Approaches to solving China's marine plastic pollution and $\mathrm{CO} 2$ emission problems. Economic Systems Research, 2019. 31(2): p. 143-157.

3. Zhu, $\mathrm{H}$., et al., The effects of $F D I$, economic growth and energy consumption on carbon emissions in ASEAN-5: evidence from panel quantile regression. Economic Modelling, 2016. 58: p. 237-248.

4. Zhou, C., H. Xie, and X. Zhang, Does Fiscal Policy Promote Third-Party Environmental Pollution Control in China? An Evolutionary Game Theoretical Approach. Sustainability, 2019. 11(16): p. 4434.

5. Asongu, S.A. and N.M. Odhiambo, Environmental degradation and inclusive human development in subSaharan Africa. Sustainable Development, 2019. 27(1): p. 25-34.

6. Shahbaz, M. and A. Sinha, Environmental Kuznets curve for CO2 emissions: a literature survey. Journal of Economic Studies, 2019. 46(1): p. 106-168. 
7. Adamu, T.M. and M. Shafiq, Analyzing the Impact of Energy, Export Variety, and FDI on Environmental Degradation in the Context of Environmental Kuznets Curve Hypothesis: A Case Study of India. Energies, 2019. 12(6): p. 1076.

8. Albulescu, C.T., et al., FDI, income, and environmental pollution in Latin America: Replication and extension using panel quantiles regression analysis. Energy Economics, 2019: p. 104504.

9. Waqih, M.A.U., et al., Rising environmental degradation and impact of foreign direct investment: An empirical evidence from SAARC region. Journal of environmental management, 2019. 243: p. 472-480.

10. Seetanah, B., et al., Impact of economic and financial development on environmental degradation: evidence from small island developing states (SIDS). Emerging Markets Finance and Trade, 2019. 55(2): p. 308-322.

11. Zafar, M.W., S. Saud, and F. Hou, The impact of globalization and financial development on environmental quality: evidence from selected countries in the Organization for Economic Co-operation and Development (OECD). Environmental Science and Pollution Research, 2019. 26(13): p. 1324613262.

12. Adu, D.T. and E.K. Denkyirah, Economic growth and environmental pollution in West Africa: Testing the Environmental Kuznets Curve hypothesis. Kasetsart Journal of Social Sciences, 2018.

13. Saud, S., S. Chen, and A. Haseeb, Impact of financial development and economic growth on environmental quality: an empirical analysis from Belt and Road Initiative (BRI) countries. Environmental Science and Pollution Research, 2019. 26(3): p. 2253-2269.

14. Mbarek, M.B., K. Saidi, and M.M. Rahman, Renewable and non-renewable energy consumption, environmental degradation and economic growth in Tunisia. Quality \& Quantity, 2018. 52(3): p. 11051119.

15. Rafindadi, A.A., I.M. Muye, and R.A. Kaita, The effects of FDI and energy consumption on environmental pollution in predominantly resource-based economies of the GCC. Sustainable Energy Technologies and Assessments, 2018. 25: p. 126-137.

16. Prăvălie, R., Drylands extent and environmental issues. A global approach. Earth-Science Reviews, 2016. 161: p. 259-278.

17. Colantoni, A., et al., Assessing trends in climate aridity and vulnerability to soil degradation in Italy. Ecological indicators, 2015. 48: p. 599-604.

18. de Angelis, E.M., M. Di Giacomo, and D. Vannoni, Climate Change and Economic Growth: The Role of Environmental Policy Stringency. Sustainability, 2019. 11(8): p. 2273.

19. Asongu, S.A., S. Le Roux, and N. Biekpe, Enhancing ICT for environmental sustainability in sub-Saharan Africa. Technological Forecasting and Social Change, 2018. 127: p. 209-216.

20. Al-Nuaimi, S., A.-A.A. Banawi, and S.G. Al-Ghamdi, Environmental and Economic Life Cycle Analysis of Primary Construction Materials Sourcing under Geopolitical Uncertainties: A Case Study of Qatar. Sustainability, 2019. 11(21): p. 6000.

21. Akins, A., et al., The universal precautionary principle: New pillars and pathways for environmental, sociocultural, and economic resilience. Sustainability, 2019. 11(8): p. 2357. 
22. Alola, A.A., The trilemma of trade, monetary and immigration policies in the United States: Accounting for environmental sustainability. Science of The Total Environment, 2019. 658: p. 260-267.

23. Harring, N. and S.C. Jagers, Why do people accept environmental policies? The prospects of higher education and changes in norms, beliefs and policy preferences. Environmental Education Research, 2018. 24(6): p. 791-806.

24. Jia, F., et al., Sustainable supply chain management in developing countries: An analysis of the literature. Journal of Cleaner Production, 2018. 189: p. 263-278.

25. Hanif, I., et al., Fossil fuels, foreign direct investment, and economic growth have triggered $\mathrm{CO} 2$ emissions in emerging Asian economies: some empirical evidence. Energy, 2019. 171: p. 493-501.

26. Saidi, K. and M.B. Mbarek, The impact of income, trade, urbanization, and financial development on CO 2 emissions in 19 emerging economies. Environmental Science and Pollution Research, 2017. 24(14): $p$. $12748-12757$.

27. Nasir, M.A., T.L.D. Huynh, and H.T.X. Tram, Role of financial development, economic growth \& foreign direct investment in driving climate change: $A$ case of emerging ASEAN. Journal of environmental management, 2019. 242: p. 131-141.

28. Pao, H.-T. and C.-M. Tsai, Multivariate Granger causality between CO2 emissions, energy consumption, FDI (foreign direct investment) and GDP (gross domestic product): evidence from a panel of BRIC (Brazil, Russian Federation, India, and China) countries. Energy, 2011. 36(1): p. 685-693.

29. Zhang, C. and X. Zhou, Does foreign direct investment lead to lower CO2 emissions? Evidence from a regional analysis in China. Renewable and Sustainable Energy Reviews, 2016. 58: p. 943-951.

30. Tang, C.F. and B.W. Tan, The impact of energy consumption, income and foreign direct investment on carbon dioxide emissions in Vietnam. Energy, 2015. 79: p. 447-454.

31. Liu, Y., Y. Hao, and Y. Gao, The environmental consequences of domestic and foreign investment: evidence from China. Energy Policy, 2017. 108: p. 271-280.

32. Jiang, L., et al., Does foreign direct investment drive environmental degradation in China? An empirical study based on air quality index from a spatial perspective. Journal of cleaner production, 2018. 176: $p$. 864-872.

33. Hitam, M.B. and H.B. Borhan, FDI, growth and the environment: impact on quality of life in Malaysia. Procedia-Social and Behavioral Sciences, 2012. 50: p. 333-342.

34. Lau, L.-S., C.-K. Choong, and Y.-K. Eng, Investigation of the environmental Kuznets curve for carbon emissions in Malaysia: do foreign direct investment and trade matter? Energy Policy, 2014. 68: p. 490497.

35. Alfaro, L., et al., FDI and economic growth: the role of local financial markets. Journal of international economics, 2004. 64(1): p. 89-112.

36. Sghaier, I.M. and Z. Abida, Foreign direct investment, financial development and economic growth: Empirical evidence from North African countries. Journal of International and Global Economic Studies, 2013. 6(1): p. 1-13.

37. Ashraf, A., D. Herzer, and P. Nunnenkamp, The effects of Greenfield FDI and cross-border M\&As on total factor productivity. The world economy, 2016. 39(11): p. 1728-1755. 
38. Johnson, A., The effects of FDI inflows on host country economic growth. The Royal Institute of technology. Centre of Excellence for studies in Science and Innovation http://www. infra. kth. se/cesis/research/publications/working papers, 2006.

39. Herzer, D., P. Hühne, and P. Nunnenkamp, FDI and Income Inequality-Evidence from L atin A merican Economies. Review of Development Economics, 2014. 18(4): p. 778-793.

40. Degong, M., et al., Do International Capabilities and Resources Configure Firm's Sustainable Competitive Performance? Research within Pakistani SMEs. Sustainability, 2018. 10(11): p. 4298.

41. Douglass, M. and O.G. Ling, Industrialising Cities and the Environment in Pacific Asia: Toward a policy framework and agenda for action, in Asia's Clean Revolution. 2017, Routledge. p. 104-127.

42. Cole, M.A., Trade, the pollution haven hypothesis and the environmental Kuznets curve: examining the linkages. Ecological economics, 2004. 48(1): p. 71-81.

43. Kuznets, S., Economic growth of countries. 1985, Beijing: Commercial Press.

44. Özokcu, S. and Ö. Özdemir, Economic growth, energy, and environmental Kuznets curve. Renewable and Sustainable Energy Reviews, 2017. 72: p. 639-647.

45. Song, M.-L., W. Zhang, and S.-H. Wang, Inflection point of environmental Kuznets curve in Mainland China. Energy policy, 2013. 57: p. 14-20.

46. Kuznets, S., Economic growth and income inequality. The American economic review, 1955. 45(1): p. 128.

47. Grossman, G.M. and A.B. Krueger, Environmental impacts of a North American free trade agreement. 1991, National Bureau of Economic Research.

48. Shafik, N., Economic development and environmental quality: an econometric analysis. Oxford economic papers, 1994. 46(4): p. 757-774.

49. Orubu, C.O. and D.G. Omotor, Environmental quality and economic growth: Searching for environmental Kuznets curves for air and water pollutants in Africa. Energy Policy, 2011. 39(7): p. 4178-4188.

50. Onafowora, O.A. and O. Owoye, Bounds testing approach to analysis of the environment Kuznets curve hypothesis. Energy Economics, 2014. 44: p. 47-62.

51. Al-Mulali, U., S.A. Solarin, and I. Ozturk, Investigating the presence of the environmental Kuznets curve (EKC) hypothesis in Kenya: an autoregressive distributed lag (ARDL) approach. Natural Hazards, 2016. 80(3): p. 1729-1747.

52. Apergis, N., Environmental Kuznets curves: New evidence on both panel and country-level CO2 emissions. Energy Economics, 2016. 54: p. 263-271.

53. Xiong, L., Z. Tu, and L. Ju, Reconciling regional differences in financial development and carbon emissions: a dynamic panel data approach. Energy Procedia, 2017. 105: p. 2989-2995.

54. Simon, H.A., Administrative behaviour. Australian Journal of Public Administration, 1950. 9(1): p. 241 245.

55. Soumaré, I. and F. Tchana Tchana, Causality between FDI and financial market development: evidence from emerging markets. The World Bank Economic Review, 2015. 29(suppl_1): p. S205-S216. 
56. Shahbaz, M., et al., Does foreign direct investment impede environmental quality in high-, middle-, and low-income countries? Energy Economics, 2015. 51: p. 275-287.

57. Solarin, S.A. and U. Al-Mulali, Influence of foreign direct investment on indicators of environmental degradation. Environmental Science and Pollution Research, 2018. 25(25): p. 24845-24859.

58. Yang, N., et al., Economic growth and pollution emission in China: Structural path analysis. Sustainability, 2018. 10(7): p. 2569.

59. Abbasi, F. and K. Riaz, CO2 emissions and financial development in an emerging economy: an augmented VAR approach. Energy Policy, 2016. 90: p. 102-114.

60. Chandran, V. and C.F. Tang, The impacts of transport energy consumption, foreign direct investment and income on CO2 emissions in ASEAN-5 economies. Renewable and Sustainable Energy Reviews, 2013. 24: p. 445-453.

61. Baek, J., A new look at the FDI-income-energy-environment nexus: dynamic panel data analysis of ASEAN. Energy Policy, 2016. 91: p. 22-27.

62. Paramati, S.R., M. Ummalla, and N. Apergis, The effect of foreign direct investment and stock market growth on clean energy use across a panel of emerging market economies. Energy Economics, 2016. 56: p. 29-41.

63. Sbia, R., M. Shahbaz, and H. Hamdi, A contribution of foreign direct investment, clean energy, trade openness, carbon emissions and economic growth to energy demand in UAE. Economic modelling, 2014. 36: p. 191-197.

64. Al-Mulali, U. and C.F. Tang, Investigating the validity of pollution haven hypothesis in the gulf cooperation council (GCC) countries. Energy Policy, 2013. 60: p. 813-819.

65. Abdouli, M. and S. Hammami, Economic growth, FDI inflows and their impact on the environment: an empirical study for the MENA countries. Quality \& Quantity, 2017. 51(1): p. 121-146.

66. Kivyiro, P. and H. Arminen, Carbon dioxide emissions, energy consumption, economic growth, and foreign direct investment: Causality analysis for Sub-Saharan Africa. Energy, 2014. 74: p. 595-606.

67. Solarin, S.A., et al., Investigating the pollution haven hypothesis in Ghana: an empirical investigation. Energy, 2017. 124: p. 706-719.

68. Mielnik, O. and J. Goldemberg, Foreign direct investment and decoupling between energy and gross domestic product in developing countries. Energy policy, 2002. 30(2): p. 87-89.

69. Lee, J.W., The contribution of foreign direct investment to clean energy use, carbon emissions and economic growth. Energy Policy, 2013. 55: p. 483-489.

70. Pazienza, P., The relationship between CO2 and Foreign Direct Investment in the agriculture and fishing sector of OECD countries: Evidence and policy considerations. Intelektinè ekonomika, 2015. 9(1): p. 5566.

71. Omri, A., D.K. Nguyen, and C. Rault, Causal interactions between CO2 emissions, FDI, and economic growth: Evidence from dynamic simultaneous-equation models. Economic Modelling, 2014. 42: p. 382389. 
72. Busse, M. and C. Hefeker, Political risk, institutions and foreign direct investment. European journal of political economy, 2007. 23(2): p. 397-415.

73. McKinnon, R. and E. Shaw, Financial deepening in economic development. Washington, Brookings Institution, 1973.

74. Alfaro, M., S. Jarvis, and P. Gregory, Factors affecting potassium leaching in different soils. Soil Use and Management, 2004. 20(2): p. 182-189.

75. Ram, R., Financial development and economic growth: Additional evidence. 1999.

76. Kapuria-Foreman, V., Economic freedom and foreign direct investment in developing countries. The Journal of Developing Areas, 2007: p. 143-154.

77. Brunetti, A. and B. Weder, Investment and institutional uncertainty: a comparative study of different uncertainty measures. Weltwirtschaftliches Archiv, 1998. 134(3): p. 513-533.

78. Wei, S.-J., Corruption, composition of capital flows, and currency crises. 2000: The World Bank.

79. Harms, P. and H.W. Ursprung, Do civil and political repression really boost foreign direct investments? Economic inquiry, 2002. 40(4): p. 651-663.

80. Jensen, N.M., Democratic governance and multinational corporations: Political regimes and inflows of foreign direct investment. International organization, 2003. 57(3): p. 587-616.

81. Li, Q. and A. Resnick, Reversal of fortunes: Democratic institutions and foreign direct investment inflows to developing countries. International organization, 2003. 57(1): p. 175-211.

82. Roe, M.J. and J.I. Siegel, Political instability and financial development. Unpublished Manuscript, Harvard Law School, 2007.

83. Harrod, R.F., An essay in dynamic theory. The economic journal, 1939. 49(193): p. 14-33.

84. Domar, E.D., Expansion and employment. The American Economic Review, 1947. 37(1): p. 34-55.

85. Rostow, W.W., The stages of economic growth. The economic history review, 1959. 12(1): p. 1-16.

86. Cui, L. and Y. Huang, Exploring the schemes for green climate fund financing: international lessons. World Development, 2018. 101: p. 173-187.

87. Hughes, H., Debt and development: The role of foreign capital in economic growth. World Development, 1979. 7(2): p. 95-112.

88. Dixon, W.J. and T. Boswell, Dependency, disarticulation, and denominator effects: Another look at foreign capital penetration. American Journal of sociology, 1996. 102(2): p. 543-562.

89. Kentor, J., The long-term effects of foreign investment dependence on economic growth, 1940-1990. American Journal of Sociology, 1998. 103(4): p. 1024-1046.

90. Solow, R.M., A contribution to the theory of economic growth. The quarterly journal of economics, 1956. 70(1): p. 65-94.

91. Swan, T.W., Economic growth and capital accumulation. Economic record, 1956. 32(2): p. 334-361.

92. Abramovitz, M., Resource and output trends in the United States since 1870, in Resource and output trends in the United States since 1870. 1956, NBER. p. 1-23.

93. Solow, R.M., Technical change and the aggregate production function. The review of Economics and Statistics, 1957: p. 312-320. 
94. Lucas, R.E., Why doesn't capital flow from rich to poor countries? American Economic Review, 1990. 80(2): p. 92-96.

95. Gourinchas, P.-O. and O. Jeanne, Capital flows to developing countries: The allocation puzzle. Review of Economic Studies, 2013. 80(4): p. 1484-1515.

96. Blomstrom, M., R.E. Lipsey, and M. Zejan, What explains the growth of developing countries? Convergence of productivity: Cross-national studies and historical evidence, 1994: p. 243-259.

97. Balasubramanyam, V.N., M. Salisu, and D. Sapsford, Foreign direct investment and growth in EP and IS countries. The economic journal, 1996. 106(434): p. 92-105.

98. Blomström, M. and A. Kokko, Multinational corporations and spillovers. Journal of Economic surveys, 1998. 12(3): p. 247-277.

99. Blomström, M. and A. Kokko, Regional integration and foreign direct investment: A conceptual framework and three cases. 1999: The World Bank.

100. Lucas Jr, R.E., On the mechanics of economic development. Journal of monetary economics, 1988. 22(1): p. 3-42.

101. Barro, R.J., Government spending in a simple model of endogeneous growth. Journal of political economy, 1990. 98(5, Part 2): p. S103-S125.

102. Romer, P.M., Endogenous technological change. Journal of political Economy, 1990. 98(5, Part 2): p. S71-S102.

103. Young, S. and P. Lan, Technology transfer to China through foreign direct investment. Regional studies, 1997. 31(7): p. 669-679.

104. Salahuddin, M., et al., The effects of electricity consumption, economic growth, financial development and foreign direct investment on CO2 emissions in Kuwait. Renewable and Sustainable Energy Reviews, 2018. 81: p. 2002-2010.

105. Shahbaz, M., et al., Economic growth, energy consumption, financial development, international trade and CO2 emissions in Indonesia. Renewable and Sustainable Energy Reviews, 2013. 25: p. 109-121.

106. Sadorsky, P., Financial development and energy consumption in Central and Eastern European frontier economies. Energy policy, 2011. 39(2): p. 999-1006.

107. Islam, F., et al., Financial development and energy consumption nexus in Malaysia: a multivariate time series analysis. Economic Modelling, 2013. 30: p. 435-441.

108. Shahbaz, M., et al., Bounds testing approach to analyzing the environment Kuznets curve hypothesis with structural beaks: The role of biomass energy consumption in the United States. Energy Economics, 2017. 68: p. 548-565.

109. Tamazian, A., J.P. Chousa, and K.C. Vadlamannati, Does higher economic and financial development lead to environmental degradation: evidence from BRIC countries. Energy policy, 2009. 37(1): p. 246253.

110. Tamazian, A. and B.B. Rao, Do economic, financial and institutional developments matter for environmental degradation? Evidence from transitional economies. Energy Economics, 2010. 32(1): p. 137-145. 
111. Jalil, A. and M. Feridun, The impact of growth, energy and financial development on the environment in China: a cointegration analysis. Energy Economics, 2011. 33(2): p. 284-291.

112. Shahbaz, M., et al., Does financial development reduce CO2 emissions in Malaysian economy? A time series analysis. Economic Modelling, 2013. 35: p. 145-152.

113. Dogan, E. and F. Seker, The influence of real output, renewable and non-renewable energy, trade and financial development on carbon emissions in the top renewable energy countries. Renewable and Sustainable Energy Reviews, 2016. 60: p. 1074-1085.

114. Zhang, Y.-J., The impact of financial development on carbon emissions: An empirical analysis in China. Energy Policy, 2011. 39(4): p. 2197-2203.

115. Shahbaz, M., et al., Financial development and environmental quality: the way forward. Energy Policy, 2016. 98: p. 353-364.

116. Javid, M. and F. Sharif, Environmental Kuznets curve and financial development in Pakistan. Renewable and Sustainable Energy Reviews, 2016. 54: p. 406-414.

117. Ozturk, I. and A. Acaravci, The long-run and causal analysis of energy, growth, openness and financial development on carbon emissions in Turkey. Energy Economics, 2013. 36: p. 262-267.

118. Omri, A., et al., Financial development, environmental quality, trade and economic growth: What causes what in MENA countries. Energy Economics, 2015. 48: p. 242-252.

119. Bekhet, H.A., A. Matar, and T. Yasmin, CO2 emissions, energy consumption, economic growth, and financial development in GCC countries: Dynamic simultaneous equation models. Renewable and Sustainable Energy Reviews, 2017. 70: p. 117-132.

120. Charfeddine, L. and K.B. Khediri, Financial development and environmental quality in UAE: Cointegration with structural breaks. Renewable and Sustainable Energy Reviews, 2016. 55: p. 1322-1335.

121. Çoban, S. and M. Topcu, The nexus between financial development and energy consumption in the EU: A dynamic panel data analysis. Energy Economics, 2013. 39: p. 81-88.

122. Ferrara, M., et al., A continuous time economic growth model with time delays in environmental degradation. Journal of Information and Optimization Sciences, 2019. 40(1): p. 185-201.

123. Raworth, K., Doughnut economics: seven ways to think like a 21st-century economist. 2017: Chelsea Green Publishing.

124. Al-Mulali, U. and I. Ozturk, The investigation of environmental Kuznets curve hypothesis in the advanced economies: the role of energy prices. Renewable and Sustainable Energy Reviews, 2016. 54: p. 16221631.

125. Atasoy, B.S., Testing the environmental Kuznets curve hypothesis across the US: Evidence from panel mean group estimators. Renewable and Sustainable Energy Reviews, 2017. 77: p. 731-747.

126. Hu, J., et al., Environmental regulation, foreign direct investment and green technological progressEvidence from Chinese manufacturing industries. International journal of environmental research and public health, 2018. 15(2): p. 221.

127. Lan, J., M. Kakinaka, and X. Huang, Foreign direct investment, human capital and environmental pollution in China. Environmental and Resource Economics, 2012. 51(2): p. 255-275. 
128. Opoku, E.E.O., M. Ibrahim, and Y.A. Sare, Foreign Direct Investment, Sectoral Effects and Economic Growth in Africa. International Economic Journal, 2019: p. 1-20.

129. Kalai, M. and N. Zghidi, Foreign direct investment, trade, and economic growth in MENA countries: empirical analysis using ARDL bounds testing approach. Journal of the Knowledge Economy, 2019. 10(1): p. 397-421.

130. Bermejo Carbonell, J. and R.A. Werner, Does foreign direct investment generate economic growth? A new empirical approach applied to Spain. Economic Geography, 2018. 94(4): p. 425-456.

131. Memon, A., Z.Y. An, and M.Q. Memon, Does financial availability sustain financial, innovative, and environmental performance? Relation via opportunity recognition. Corporate Social Responsibility and Environmental Management, 2019.

132. Songling, Y., et al., The role of government support in sustainable competitive position and firm performance. Sustainability, 2018. 10(10): p. 3495.

133. Dutta, N. and S. Roy, Foreign direct investment, financial development and political risks. The Journal of Developing Areas, 2011: p. 303-327.

134. Otchere, I., I. Soumaré, and P. Yourougou, FDI and financial market development in Africa. The World Economy, 2016. 39(5): p. 651-678.

135. Shahbaz, M., M.A. Nasir, and D. Roubaud, Environmental degradation in France: the effects of FDI, financial development, and energy innovations. Energy Economics, 2018. 74: p. 843-857.

136. Sirag, A., S. SidAhmed, and H.S. Ali, Financial development, FDI and economic growth: evidence from Sudan. International Journal of Social Economics, 2018. 45(8): p. 1236-1249.

137. Narayan, P.K. and S. Narayan, Carbon dioxide emissions and economic growth: Panel data evidence from developing countries. Energy policy, 2010. 38(1): p. 661-666.

138. King, R.G., a Ross LEVINE. Finance and growth. Schumpeter Might Be Right. Country economic department. The World Bank, 1993.

139. Seetanah, B., Financial development and economic growth: an ARDL approach for the case of the small island state of Mauritius. Applied Economics Letters, 2008. 15(10): p. 809-813.

140. George, D. and P. Mallery, IBM SPSS statistics 23 step by step: A simple guide and reference. 2016: Routledge.

141. Anwar, M., Business model innovation and SMEs performance-does competitive advantage mediate? International Journal of Innovation Management, 2018. 22(07): p. 1850057.

142. Gujarati, D.N., Basic econometrics. 2009: Tata McGraw-Hill Education.

143. Baron, R.M. and D.A. Kenny, The moderator-mediator variable distinction in social psychological research: Conceptual, strategic, and statistical considerations. Journal of personality and social psychology, 1986. 51(6): p. 1173.

144. Shaw, E.S., Financial deepening in economic development. 1973.

145. Raza, S.A., N. Shah, and A. Sharif, Time frequency relationship between energy consumption, economic growth and environmental degradation in the United States: Evidence from transportation sector. Energy, 2019. 173: p. 706-720. 
146. Shahbaz, M., I. Haouas, and T.H. Van Hoang, Economic growth and environmental degradation in Vietnam: Is the environmental Kuznets curve a complete picture? Emerging Markets Review, 2019. 38: p. 197-218.

147. Koengkan, M., L.D. Losekann, and J.A. Fuinhas, The relationship between economic growth, consumption of energy, and environmental degradation: renewed evidence from Andean community nations. Environment Systems and Decisions, 2019. 39(1): p. 95-107.

148. Haseeb, A., et al., Does information and communication technologies improve environmental quality in the era of globalization? An empirical analysis. Environmental Science and Pollution Research, 2019. 26(9): p. 8594-8608.

149. Saint Akadiri, S., et al., Towards achieving environmental sustainability target in Italy. The role of energy, real income and globalization. Science of The Total Environment, 2019. 671: p. 1293-1301.

\section{Figures}

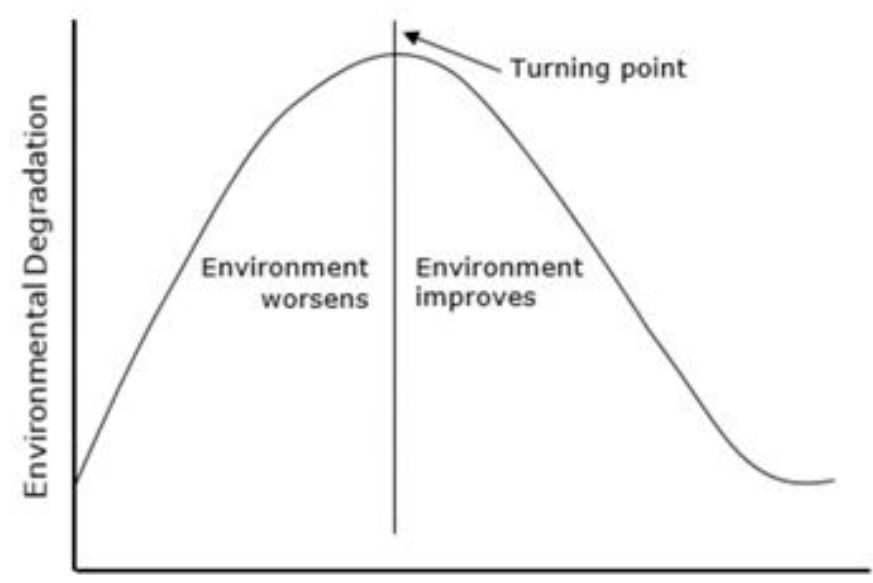

Per Capita Income

Figure 1

Environmental Kuznets curve. 